Int. J. Dev. Biol. 57: 587-593 (2013)

doi: $10.1387 / \mathrm{ijdb} .130266 \mathrm{ad}$

\title{
Role of plant expression systems in antibody production for passive immunization
}

\author{
VIKRAM VIRDI and ANN DEPICKER* \\ Department of Plant Systems Biology, VIB, and Department of Plant Biotechnology and Bioinformatics, \\ Ghent University, Gent, Belgium
}

\begin{abstract}
Passive immunization is a method to achieve immediate protection against infectious agents by administering pathogen-specific antibodies. It has proven to be lifesaving for many acute infections, and it is now also used for cancer treatment. Passive immunization therapies, however, are extremely expensive because they require large amounts of specific antibodies that are produced predominantly in mammalian expression systems. The cost for manufacturing plant-made antibodies is estimated to be comparatively low since plant production systems require relatively less capital investments. In addition, they are not prone to mammalian pathogens, which also eases downstream processing along with making it a safe expression system. Moreover, some of the recent developments in transient expression have enabled rapid, cGMP (current Good Manufacturing Practices) compliant manufacturing of antibodies. Whether lower production costs will be reflected in a lower market price for purified antibodies will be known when more plant-produced antibodies come to the market. Promisingly, the current molecular techniques in the field of in planta expression have enabled high-level production of a variety of antibodies in different plant organs, like roots/tubers/fruits, leaves and seeds, of a variety of plants, like potato, tobacco, maize, rice, tomato and pea, providing a very wide range of possible plant-based passive immunization therapies. For instance, the production of antibodies in edible tissues would allow for a unique, convenient, needle-less, oral passive immunization at the gastric mucosal surface. The technological advances, together with the innate capacity of plant tissues to assemble complex antibodies, will enable carving a niche in the antibody market. This non-exhaustive review aims to shed light on the role of plants as a flexible expression system for passive immunotherapy, which we envisage to progress alongside the conventional production platforms to manufacture specialized antibodies.
\end{abstract}

KEY WORDS: molecular farming, in leaf production, in seed production, plantibodies, disruptive technology

\section{Introduction and scope of passive immunization}

One of the most important arsenals in fighting infectious diseases is the antibody or the protein called immunoglobulin (lg). After natural infection or vaccination, the immune system is primed to produce pathogen-specific antibodies, which in turn provide protection against subsequent infection by the same pathogen (Durandy et al., 2009). As an alternative to vaccination, which is predominantly prophylactic and needs to be administered prior to the contingency of infections, 'immediate protection' can be achieved by direct administration of disease-specific protective antibodies. The administration of disease-specific antibodies either prophylactically or post-exposure is called passive immunization (Gonik, 2011, Naz and Rajesh, 2004, Raab, 2011, Zeitlin et al.,
2000, Zeitlin et al., 1999). The immediate protective effect of passive immunization is temporal, lasting up to months (Zeitlin et al., 2000), and is suitable for emergencies like protection of newborns against vertical transmission of viruses from the mother, protection against biological warfare or emerging diseases, protection of elderly and immune-compromized patients, etc.

The use of passive immunization for the prevention of infectious diseases in human subjects can be traced back to the 1800 s, when

\footnotetext{
Abbreviations used in this paper: CaMV, cauliflower mosaic virus; cGMP, current good manufacturing practices; Fc, fragment crystallizable; GM, genetically modified; Ig, immunoglobulin; ER, endoplasmic reticulum; P35S, 35S promoter; PB, protein body; PSV, protein storage vacuole; mAb, monoclonal antibody; ScFv, single chain variable fragment; $\mathrm{VHH}$, variable fragment of heavy chain only antibodies.
}

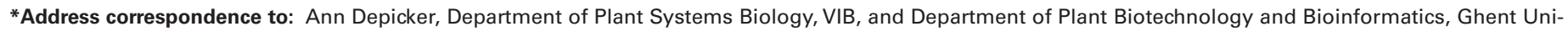
versity, Technologiepark 927, 9052 Gent, Belgium. Tel.: +32-9-331-3940. Fax: +32-9-331-3809. E-mail: ann.depicker@psb.vib-ugent.be
} 
antibodies were sought from animal sera like rabbit and horse (Eibl, 2008). However, infusion of animal serum was not tolerated, since it leads to the immune complication called 'serum sickness', particularly after repeated use. Later, human antibodies (from human convalescent sera) were available and passive immunization was largely used during World War I, to treat tetanus, diphtheria and pneumococcal disease. By the 1930s and 1940s, the advancement of fractionation techniques resulted in the separation of plasma proteins and the opportunity to administer a stable biological fraction. Such fractionated serum was used to treat poliomyelitis, mumps, measles, pertussis and even hepatitis A (Raab, 2011). With the emergence of antibiotics and vaccines, the use of passive immunization declined (Berghman et al., 2005, Hsu and Safdar, 2011), but when immediate protection is needed or when vaccines are not a choice, passive immunization is still applied (Holliger and Hudson, 2005, Naz and Rajesh, 2004). A nice example is passive immunization with anti-rabies polyclonal antibodies after being bitten by a rabid animal in regions where rabies is endemic (Both et al., 2012). Moreover, antibiotic replacement is actively sought given the risk of introducing resistant bacterial strains. It is anticipated that passive immunization will regain popularity and might reduce the dependency on the traditionally used antibiotic therapy (Berghman et al., 2005, Oleksiewicz et al., 2012, Zeitlin et al., 2000).

The antibody technology has been developed in leaps and bounds. Specific high quality antibodies against one specific epitope, called monoclonal antibodies (mAbs), can be produced using hybridoma technology, involving the fusion of spleen cells from an immunized mouse (or rat) with immortalized myeloma cells (Köhler and Milstein, 1975). Today, this platform contributes to some of the major demands of monoclonal antibodies in research and diagnostics. However, for therapeutic application, the use of murine $\operatorname{lgG}$ is discouraged due to possible side effects arising from an immune response to foreign lgGs. Hence, for human application, humanized or at least partially humanized antibodies are needed. The production of human hybridomas has been difficult; instead B cells from transgenic mice with the human $\lg$ gene repertoire are used to generate humanized Ig (Brüggemann et al., 1989, Schirrmann et al., 2008). There are some drawbacks to the hybridoma technology for passive immunization, as it is inefficient to produce antibodies against toxins and conserved antigens, and it requires immunization and the development of an in vivo immune response (Schirrmann et al., 2008). In vitro technologies, like phage display, have liberated it from these constraints, and the antigen-binding antibody domains can be quickly sequenced (Smith, 1985). Recently, the in vitro technology for the development of human mAbs directly from a single $B$ cell derived from an ampule of peripheral blood mononucleocytes has been well established (Tiller et al., 2008). This is done by sequestering the specific antibody encoding genes using state of the art molecular biology tools. These gene sequences can then be optimized for expression in various systems. This technique has greatly contributed to the discovery and development of antibodies, in particularly for HIV neutralizing antibodies from infected donors (Andrabi et al., 2012). The technological developments have thus given a boost to the passive immunization field and aim to provide part of the solution for the increased disease burden and emergence of new pathogens.

Passive immunization is currently also used to treat non-infectious diseases, like cancer (e.g. FDA approved Bevacizumab and Cetuximab for colon cancer, Alemtuzumab for chronic lymphocytic leukaemia), autoimmune diseases (e.g. FDAapprovedAdalimumab for rheumatoid arthritis) and Alzheimer (Bapineuzumab and Solanezumab are being evaluated in clinical trials) (Casadevall et al., 2004, Holliger and Hudson, 2005, Zeitlin et al., 2000). Antibodies specific for drugs, like cocaine and nicotine, are also investigated to regulate and control drug abuse by preventing their access to the brain, and thus regulating the drug-induced effects. Currently ongoing clinical trials will provide more information about this novel application of antibody therapy (Kosten and Owens, 2005).

Mucosal surfaces comprising the respiratory, gastrointestinal, reproductive and genital tract are the gateways for most pathogenic infections. Most vaccines fail to achieve a systemic, as well as a mucosal immune response. Topical application of antibodies at the mucosal surface can immediately prevent pathogenic invasion at the first port of entry (Corthésy, 2003, Corthésy and Spertini, 1999). A mixture of three mAbs (2G12, $2 \mathrm{~F} 5$ and $4 \mathrm{E} 10)$, as a $\mathrm{mAbGel}$ is being evaluated in a clinical trial as vaginal microbicide for the prevention of HIV in heterosexual couples. Development of such microbicides against sexually transmitted diseases is very important in preventing unsafe sex-related death and disability (Whaley et al., 2011).

When it comes to the recombinant production of antibodies, mammalian cell cultures have been readily better suited to obtain highly functional proteins with proper glycosylation, as compared to other prokaryotic and eukaryotic platforms. Therefore, the majority of clinical therapeutic antibodies are produced in mammalian cells, despite the high production costs. The yield of the antibodies produced in mammalian cells has increased more than 10-fold (more than $5 \mathrm{~g} / \mathrm{L}$ ) since the $1980 \mathrm{~s}$ (Wurm, 2004). This high production level was achieved through high cell densities, high antibody expression per cell and improvement in chromosomal integration of antibody encoding genes. However, stable transformation of mammalian cells is a lengthy process. As an alternative, transient expression with viral promoters has empowered production of hundreds of milligrams of antibodies (Schirrmann et al., 2008). Nevertheless, the mammalian system is still expensive and has become the limiting factor for widespread passive immunization. Expression in transgenic plants might be a solution to effectively scale up therapeutic Igs, and lower the production costs. The recent developments in plant transformation tools have enabled effective production of almost all kinds of antibody and antibody formats, some of which, like the complex secretory $\lg \mathrm{A}(\mathrm{S} \lg \mathrm{A})$ for mucosal passive immunization, have thus far been successfully manufactured only in plants (Paul and $\mathrm{Ma}, 2011$, Virdi et al., 2013, Xu et al., 2012). Further, Igs with engineered human-like glycosylation can also be produced in plants (Webster and Thomas, 2012). In the next section we describe the plant as antibody production platform in detail, to highlight how plant expression platforms can help in sharing the load of antibody production together with the established mammalian platform. We believe its particular merits will lie in applications (i) when the antibody production cost has to be minimal, (ii) when Igs with novel complex formats are needed, (iii) for rapid production in case of emergencies like bioterrorism and (iv) in instances where plant tissues can act as a delivery system, particularly for veterinary applications.

\section{Antibody expression in plants}

The first proof of concept for functional antibody production in plants was provided in 1989, when two transgenic tobacco plants, each expressing light or heavy chains, were produced by 
Agrobacterium-mediated transformation of tobacco leaf discs (Hiatt et al., 1989). Crossing these two transgenic tobacco lines led to the expression of assembled functional IgG antibodies, accumulating up to $1.3 \%$ of total soluble protein. From then on, numerous antibodies and other proteins have been expressed in plants, demonstrating that plants can express and assemble components into functional, complex multimeric proteins (De Muynck et al., 2010, Hiatt et al., 1989, Rybicki, 2010).

Plant expression systems are an attractive platform for the production of antibodies, for several reasons. Predominantly due to the possibility of production scale-up at a fraction of the costs compared to conventional systems. It has been estimated that for plant-based antibodies expressing up to $1 \%$ of total soluble protein, the production cost would be $0.1 \%$ of that of the mammalian cell culture system and up to $2-10 \%$ of that of microbial systems (Chen et al., 2005). Another advantage is that many plant species have a 'generally regarded as safe' status, since they do not contain mammalian viruses or pathogens, or produce endotoxins. The ease of purification and downstream processing of plant-made antibodies is often postulated to result in a low cost of the final product, which can be applied parenterally, topically or orally (Xu et al., 2012). Then there is the merit of speed: using the established state of the art tobacco leaf-based transient expression system, bulk quantities of antibodies can be manufactured in a record time as compared to any other established expression system (Castilho et al., 2011) Moreover, the developments in glyco-engineering of plants has made it possible to produce antibodies with desired glycoforms. Modification of glycans has also been perfected in comparative expression systems like mammalian cell cultures, but it has been seen that glyco-engineered plants have a much higher degree of glycan homogeneity (Castilho et al., 2011, Olinger et al., 2012). Having a higher degree of desired glycosylation can lead to higher product quality and clinical efficacy; as demonstrated in case of h-13F6, an anti-Ebola virus monoclonal antibody (Olinger et al., 2012, Zeitlin et al., 2011). The plant-derived version of h13F6, bearing the complex $\mathrm{N}$-glycosylation and devoid of the core fucose, showed higher potency than the original version derived from murine cells.

In conjunction, expression in edible plant tissues like tubers, roots and seeds, is anticipated to open a new avenue for passive immunization against enteric diseases of farm animals, which so far has been impossible due to the high costs using antibodies produced through conventional systems (Floss et al., 2007). Additional benefits of in seed expression of antibodies are the storage at ambient temperature and ease of transportation, which can enable decoupling of the scale-up in the field and the downstream processing (Khan et al., 2012) and which can reduce the burden of cold chain maintenance during shipping.

\section{Different plant-based expression systems}

Several plant systems have been explored to achieve an abundant overall production of heterologous proteins with a low capital investment (reviewed in Xu et al., 2012). Antibodies have been produced in moss (Decker and Reski, 2008), microalgae (Franklin and Mayfield, 2005, Mayfield and Franklin, 2005), duckweed (Cox et al., 2006), plant cells (Hellwig et al., 2004), organ cultures (Hellwig et al., 2004, Sharp and Doran, 2001) and land plants both monocots (like maize) and dicots (like Arabidopsis, tobacco, potato, soybean, alfalfa) (De Muynck et al., 2010). All autotrophic plants have a relatively similar cellular machinery and glycosylation pattern, and most can be transformed by Agrobacterium-mediated transformation or by particle bombardment, two methods of which the former is preferred, as it tends to introduce a low T-DNA copy number in the plant genome (Cheng et al., 2004, Ko and Koprowski, 2005). After the rather time-consuming process of production and selection of homozygous plant lines showing stable antibody expression at a high level, further scale-up for future bulk production can be done with existing farming infrastructure. Alternatively to the development of stably expressing transgenic plant lines, quick protein production can be obtained by transient expression using Agrobacterium infiltration (Kapila et al., 1997) or viral vector expression systems (Gleba et al., 2005, Mor et al., 2003), each having its own benefits.

Depending on the antibody or antibody fragment to be expressed, the downstream processes, the delivery system, etc., the most applicable plant expression system needs to be chosen. However, currently leaves, followed by plant culture systems (hairy roots, cell culture, etc.) and seeds, are most widely used, given the obtained quality and quantity of the recombinant antibody. Here, we review the in leaf and in seed expression systems. For more information about plant culture systems, we recommend the review from $\mathrm{Xu}$ et al. (2011).

\section{In leaf antibody expression}

The most important motivation for antibody production in leaves is the capacity to scale-up and obtain a high amount of biomass through multiple harvests per year. Until 2010, more than $50 \%$ of plant-made full length antibodies were expressed in leaves (De Muynck et al., 2010). Of the plant species that have been explored for in leaf production of antibody and antibody fragments, tobacco (mostly Nicotiana tabacum and $N$. benthamiana species) has emerged as one of the leading platforms (Paul and Ma, 2011), as it can produce yields of up to 300 tons of biomass per acre, can be conveniently grown in field as well as in greenhouses, and is not regarded as a feed/food plant. More importantly, genetic manipulations of tobacco are easy, and antibody genes can be introduced both stably in the nucleus via Agrobacterium-mediated transformation, or transiently by Agrobacterium infiltration or by viral vectors (Whaley et al., 2011).

One of the most successful examples of a tobacco-made antibody for passive prophylaxis is the secretory antibody CaroRx ${ }^{\mathrm{TM}}$ from Planet Biotechnology (www.planetbiotechnology.com), which is now available within the European Union for the prevention of dental caries. Recombinant production of these hetero-decameric SIgAs is commercially not feasible by conventional production systems, and to date plants remain the only viable platform for the production of SIgAs (Paul and Ma, 2011). All elements needed for the expression of SIgAs are introduced in one plant line by successive crossing of individual tobacco lines expressing the light and heavy chains, the joining chain, and the secretory component (Ma et al., 1995, Wycoff, 2005). The combination of stable nuclear transformation and classical breeding has proven to be a robust system for the production of such complex antibodies (Paul and $\mathrm{Ma}, 2011)$. Based on the same strategy, Planet Biotechnology has developed two other promising products: DoxoR $x^{\mathrm{TM}}$ for drug-induced alopecia, a common side effect of cancer therapy, and RhinoRx ${ }^{\mathrm{TM}}$ 
for the treatment of colds.

Another successful example of stable expression of antibodies in tobacco leaves is the 2 G12 anti-HIV antibody. This antibody was isolated from human sera and has drawn the attention due to its characteristic property to neutralize various isolates of the HIV virus (Paul and Ma, 2011, Trkola et al., 1996). This antibody was expressed under the control of a constitutive promoter and tissue-specific promoters in seeds of maize (Rademacher et al., 2008, Ramessar et al., 2008) and Arabidopsis (Loos et al., 2011a), and in tobacco leaves. The $2 \mathrm{G} 12$ antibody-producing tobacco plants were grown in a contained greenhouse in compliance to cGMP procedures at Fraunhofer IME, Aachen, Germany (Paul et al., 2011), and immediately purified on site by a customized downstream protocol. Growing plants in regulated greenhouse conditions is advantageous as it prevents the chance of gene flow to the environment through escape of pollen and dispersal of seeds. The regulated environmental conditions within the greenhouse, like temperature, humidity, etc. also enable maintenance of quality and quantity from one batch to another, as it has been noted that biotic and abiotic factors do affect the yield of plant-made recombinant proteins (Paul and Ma, 2011). Production in greenhouses increases the costs as compared to field-grown therapeutic antibodies, but on the other side, it paves the way for establishing regulatory procedures (Paul and Ma, 2011, Paul et al., 2011).

There are several excellent transient expression systems developed that enable large-scale production of recombinant proteins, including antibodies, in about eight days after cloning of the target gene DNA. Some of these include virus-based expression systems, like magnICON® (Gleba et al., 2005), Gemini (Huang et al., 2010) and Geneware (Pogue et al., 2010); and engineered vectors for Agrobacterium-infiltration, like the $\mathrm{pEAQ}$ system, in which the T-DNA also bears the p19 viral silencing suppressor (Sainsbury et al., 2010, Sainsbury et al., 2009, Voinnet et al., 2003). The possibility of high-scale antibody production in the limited space of greenhouses and over a short period of time enables multiple rounds of production. This also eases the downstream processing and enables a high recovery of purified antibody. Companies and institutions like Medicago (Quebec city, Quebec, Canada), Kentucky BioProcesses (Owensboro, Kentucky, USA), Texas A\&M (college station, Texas, USA), Fraunhofer (Newark, USA) and Icon Genetics (Bayer, Halle, Germany) have established infrastructures for large-scale automated systems to grow tobacco plants in the greenhouse, infiltrate/infect, and harvest the protein (Whaley et al., 2011). Once the antibody genes are isolated and cloned, within two weeks the antibody can be administered to the patient (Paul and Ma, 2011, Whaley et al., 2011). Adisadvantage of the transient system is that the leaves have to be processed immediately for optimal product recovery. Also, Agrobacterium infiltration entails the presence of a large amount of bacterial cells, introducing the risk of bacterial endotoxin contamination. However, innovative, cost-effective purification systems, like the tobamovirus-protein A fusion, are being developed (Werner et al., 2006). Taken all together, the tobacco leaf-based expression system, both stable as well as transient, seems very promising.

\section{In seed antibody expression}

Seeds can be considered as a natural protein production factory and storage house. In addition to the merits of in planta expression, in seed expression enables oral delivery, long-term storage, and ease of handling and transport without cold chain maintenance (Floss et al., 2007, Khan et al., 2012). Seeds can be used directly for passive mucosal immunization, which is particularly advantageous for animal diseases (Floss et al., 2007, Zimmermann et al., 2009), and also for human application. Alternatively, for parenteral application, the high protein concentration in desiccated seeds facilitates the downstream processing. Different full-length antibody and antibody formats, like ScFv, ScFv-Fc, VHHs and VHH-Fc, have been expressed effectively in seeds of both monocot and dicot plants (De Wilde et al., 2013, Khan et al., 2012, Loos et al., 2011b, Van Droogenbroeck et al., 2009, Virdi et al., 2013).

Although the use of the constitutive Cauliflower mosaic virus (CaMV) 35S promoter (P35S) to drive transgene expression can yield high amounts of antibodies in various plant tissues, its strength in controlling expression in seeds is poor, and a seedspecific promoter, like the $\beta$-phaseolin promoter leading to high accumulation is required (De Jaeger et al., 2002, De Wilde et al., 2013, Van Droogenbroeck et al., 2007). It is reasoned that the seed-specific promoters are usually active during the seed filling stage (development and maturity), while the CaMV P35S ceases expression after the initial stages, explaining the lower accumulation (Chen etal., 1986, Petruccelli et al., 2006). Besides the $\beta$-phaseolin promoter (De Jaeger et al., 2002, De Wilde et al., 2013), several other seed-specific promoters, like USP (unknown seed promoter) (Zimmermann et al., 2009), glutelin-1 (gt-1) promoter (Ramessar et al., 2008), legumin A promoter (Perrin et al., 2000), and maize ubiquitin promoter (Christensen and Quail, 1996), have been evaluated for the expression of antibodies and other therapeutic proteins in plants (Khan et al., 2012).

Overall it has been seen that promoters specific for endosperm, in case of the monocot seeds, and those specific for cotyledons (i.e. the embryo), in case of dicot seeds, generally lead to high expression (Khan et al., 2012). Both these respective compartments are the protein sinks of the seed. Although compartment-specific promoters play a big role in the level of accumulation, they are not the sole factor (Drakakaki et al., 2006, Streatfield, 2007), since subcellular trafficking and accumulation play an equally important role. The endomembrane system of seeds differs from that of the other vegetative tissues. Seed cells have specialized subcellular structures called protein bodies (PBs), protein storage vacuoles (PSVs), starch granules and oil bodies. Some of these organelles, like PSVs and PBs, allow stable storage of antibodies, influencing their stability, accumulation and thus overall yield (Khan et al., 2012, Stöger et al., 2000). However, targeting the recombinant protein to a particular subcellular compartment can be difficult, since trafficking of native storage proteins is very complex and depends on the storage protein and the plant species (Khan et al., 2012). For instance, globulins and albumins are predominant storage proteins of many seeds, which usually reach the end destination of PSVs via the Golgi apparatus via dense vesicles, however in pumpkin seeds these proteins reach PSVs by omitting the Golgi apparatus, but instead traffic through precursor-accumulating vesicles (Hara-Nishimura et al., 1998, Hohl et al., 1996). Despite these complications in targeting recombinant proteins in seeds, the use of signal peptides of endogenous seed proteins and of the KDEL endoplasmic reticulum (ER) retention signal, has enabled the successful expression and stable accumulation of several recombinant proteins in seed storage organelles (De Jaeger et al., 
2002, Peters and Stoger, 2011). Secreting antibodies (by addition of an N-terminal signal peptide), and retaining them within the endomembrane system (with a C-terminal KDEL/SEKDEL peptide) in general is a preferred strategy for in seed antibody production. The specific retention also enables posttranslational modification like addition of glycans (Loos et al., 2011a). The glycosylation of proteins up to the ER is similar in yeast, plants and animals (Berends et al., 2009). Thus, the addition of plant-specific glycans is avoided by retention in the ER, especially in cases where glycosylation is important for efficacy in case of passive immunization therapy or intravenous administration.

It has been suggested that the bio-encapsulation in endomembranes protects proteins from the harsh gastric environment after oral delivery of crude or semi-processed seeds. When chickens were forced fed with pea seeds bearing anti-Eimeria ScFv, they were protected from subsequent coccidiosis, while purified antibodies (produced from tobacco leaves) failed to provide similar protection (Zimmermann et al., 2009).

\section{Conclusion}

Despite the several advantages of plants as antibody expression systems, there are only a few antibodies that have made it through the clinical phase, such as the tobacco-produced CaroRx ${ }^{\mathrm{TM}}$ (Obembe et al., 2011). One of the main reasons for this delay in bringing plant-made therapeutic antibodies to the market could be the regulatory issues associated with genetically modified (GM) plants and the already established mammalian systems for monoclonal antibody production (Paul and Ma, 2011). Contamination of the environment with GM plants can be a serious issue. However, things are now changing mostly due to the development of expression technologies that have enabled transformation of different plant species, some of which can grow fast and produce large amounts of biomass in a short time. Moreover, the expression vectors have been improved, which enables high levels of antibody production from a reasonably small plant biomass (Paul and Ma, 2011, Whaley et al., 2011, Xu et al., 2012). This means that a substantial amount of antibody can be harvested from a limited number of plants that can be grown in contained glass facilities rather than on large open fields as initially anticipated. There is hope that in the near future the full potential of plants as a cost-effective platform would be realized.

So is plant expression the next disruptive technology for antibody production? In our opinion, perhaps not. It's rather a niche technology. This is because the mammalian antibody expression system is well established, these antibodies are in clinics now and have thus gone through the cGMP production and drug regulation. Production of these clinically used antibodies in a new production platform as a 'biosimilar' is perhaps not worthwhile, given that it will have to go through regulatory compliance and although production costs might be lower than that of the mammalian expression system, it is uncertain if the market price of plant-made biosimilar antibodies would be significantly cheaper. However, the advantage of plants not harboring mammalian pathogens needs to be considered. One of the core strength of the plant expression system would be the production of 'biobetters', i.e therapeutics with enhanced features attributing to enhanced efficacy, which is a notion shared by many leading experts in the field of plant molecular farming (Plant Based Vaccine, Antibodies and Biologics Conference 2013). Plant-made biobetter antibodies can be produced by banking on the strength of plant expression systems, particularly the rapid antibody production via automated cGMP transient tobacco expression systems, the homogenous glyco-engineered antibody production, the production of complex SIgA and IgM antibodies, which can enable effective delivery via the oral route (Virdi et al., 2013). Thus, the plant expression technology is not a disruptive but a niche technology, which excels in the production of certain antibodies far beyond the conventional production platforms.

\section{References}

ANDRABI R, KUMAR R, BALA M, NAIR A, BISWAS A, WIG N, KUMAR P, PAL R SINHA S, LUTHRA K. (2012). Production and characterization of human anti-V3 monoclonal antibodies from the cells of HIV-1 infected Indian donors. Virol J9: 196.

BERENDS E, SCHOLTMEIJER K, WÖSTEN HAB, BOSCH D, LUGONES LG (2009). The use of mushroom-forming fungi for the production of $\mathrm{N}$-glycosylated therapeutic proteins. Trends Microbiol 17: 439-443.

BERGHMAN LR, ABI-GHANEM D, WAGHELA SD, RICKE SC. (2005). Antibodies: An alternative for antibiotics? Poult Sci 84: 660-666.

BOTHL, BANYARDAC, VANDOLLEWEERD C, HORTON DL, MAJK-C, FOOKSAR. (2012). Passive immunity in the prevention of rabies. Lancet Infect Dis 12:397-407.

BRÜGGEMANN M, CASKEYHM, TEALE C, WALDMANN H, WILLIAMS GT, SURANI MA, NEUBERGER MS. (1989). A repertoire of monoclonal antibodies with human heavy chains from transgenic mice. Proc Natl Acad Sci USA 86: 6709-6713.

CASADEVALLA, DADACHOVA E, PIROFSKI L-A. (2004). Passive antibody therapy for infectious diseases. Nat Rev Microbiol 2: 695-703.

CASTILHO A, BOHOROVA N, GRASS J, BOHOROV O, ZEITLIN L, WHALEY K, ALTMANN F, STEINKELLNER H. (2011). Rapid high yield production of different glycoforms of Ebola virus monoclonal antibody. PLOS ONE 6: e26040.

CHEN M, LIU X, WANG Z, SONG J, QI Q, WANG PG. (2005). Modification of plant $\mathrm{N}$-glycans processing: The future of producing therapeutic protein by transgenic plants. Med Res Rev 25: 343-360.

CHEN ZL, SCHULER MA, BEACHY RN. (1986). Functional analysis of regulatory elements in a plant embryo-specific gene. Proc NatlAcad Sci USA 83: 8560-8564.

CHENG M, LOWE BA, SPENCER TM, YE X, ARMSTRONG CL. (2004). Factors influencing Agrobacterium-mediated transformation of monocotyledonous species. In vitro Cell Dev Biol-Plant 40: 31-45.

CHRISTENSENAH, QUAILPH. (1996). Ubiquitin promoter-based vectors for high-level expression of selectable and/or screenable marker genes in monocotyledonous plants. Transgenic Res 5: 213-218.

CORTHÉSYB. (2003). Recombinant secretory immunoglobulin A in passive immunotherapy: linking immunology and biotechnology. Curr Pharm Biotechnol 4: 51-67.

CORTHÉSY B, SPERTINI F. (1999). Secretory immunoglobulin A: from mucosal protection to vaccine development. Biol Chem 380: 1251-1262.

COX KM, STERLING JD, REGAN JT, GASDASKA JR, FRANTZ KK, PEELE CG, BLACK A, PASSMORE D, MOLDOVAN-LOOMIS C, SRINIVASAN M, CUISON S, CARDARELLI PM, DICKEY LF. (2006). Glycan optimization of a human monoclonal antibody in the aquatic plant Lemna minor. Nat Biotechnol 24: 1591-1597.

DE JAEGER G, SCHEFFER S, JACOBS A, ZAMBRE M, ZOBELLO, GOOSSENS A DEPICKERA, ANGENON G. (2002). Boosting heterologous protein production in transgenic dicotyledonous seeds using Phaseolus vulgaris regulatory sequences. Nat Biotechnol 20: 1265-1268.

DE MUYNCK B, NAVARRE C, BOUTRY M. (2010). Production of antibodies in plants: status after twenty years. Plant Biotechnol J 8: 529-563.

DE WILDE K, DE BUCK S, VANNESTE K, DEPICKER A. (2013). Recombinant antibody production in Arabidopsis seeds triggers an unfolded protein response. Plant Physiol 161: 1021-1033.

DECKER EL, RESKI R. (2008). Current achievements in the production of complex biopharmaceuticals with moss bioreactors. Bioprocess Biosyst Eng 31: 3-9.

DRAKAKAKI G, MARCEL S, ARCALIS E, ALTMANN F, GONZALEZ-MELENDI P, FISCHER R, CHRISTOU P, STOGER E. (2006). The intracellular fate of a recombinant protein is tissue dependent. Plant Physiol 141: 578-586.

DURANDY A, KAVERI SV, KUIJPERS TW, BASTA M, MIESCHER S, RAVETCH JV, 
RIEBEN R. (2009). Intravenous immunoglobulins - understanding properties and mechanisms. Clin Exp Immunol 158: 2-13.

EIBL MM. (2008). History of immunoglobulin replacement. Immunol Allergy Clin North Am 28: 737-764.

FLOSS DM, FALKENBURG D, CONRAD U. (2007). Production of vaccines and therapeutic antibodies for veterinary applications in transgenic plants: an overview. Transgenic Res 16: 315-332.

FRANKLIN SE, MAYFIELD SP. (2005). Recent developments in the production of human therapeutic proteins in eukaryotic algae. Expert Opin Biol Ther 5: 225-235.

GLEBA Y, KLIMYUK V, MARILLONNET S. (2005). Magnifection - a new platform for expressing recombinant vaccines in plants. Vaccine 23: 2042-2048.

GONIK B. (2011). Passive immunization: the forgotten arm of immunologically based strategies for disease containment. Am J Obstet Gynecol205: 444.e441-444.e446.

HARA-NISHIMURAI, SHIMADAT, HATANO K, TAKEUCHIY, NISHIMURAM. (1998). Transport of storage proteins to protein storage vacuoles is mediated by large precursor-accumulating vesicles. Plant Cell 10: 825-836.

HELLWIG S, DROSSARD J, TWYMAN RM, FISCHER R. (2004). Plant cell cultures for the production of recombinant proteins. Nat Biotechnol 22: 1415-1422.

HIATTA, CAFFERKEYR, BOWDISHK. (1989). Production of antibodies in transgenic plants. Nature 342: 76-78.

HOHL I, ROBINSON DG, CHRISPEELS MJ, HINZ G. (1996). Transport of storage proteins to the vacuole is mediated by vesicles without a clathrin coat. $\mathrm{J} \mathrm{Cell} \mathrm{Sci}$ 109: 2539-2550.

HOLLIGER P, HUDSON PJ. (2005). Engineered antibody fragments and the rise of single domains. Nat Biotechnol 23: 1126-1136.

HSU JL, SAFDARN. (2011). Polyclonal immunoglobulins and hyperimmune globulins in prevention and management of infectious diseases. Infect Dis Clin North Am 25: 773-788.

HUANG Z, PHOOLCHAROEN W, LAI H, PIENSOOK K, CARDINEAU G, ZEITLIN L, WHALEY KJ, ARNTZEN CJ, MASON HS, CHEN Q. (2010). High-level rapid production of full-size monoclonal antibodies in plants by a single-vector DNA replicon system. Biotechnol Bioeng 106: 9-17.

KAPILAJ, DE RYCKE R, VANMONTAGU M, ANGENON G. (1997). An Agrobacteriummediated transient gene expression system for intact leaves. Plant Sci122: 101-108.

KHAN I, TWYMAN RM, ARCALIS E, STOGER E. (2012). Using storage organelles for the accumulation and encapsulation of recombinant proteins. Biotechnol $J$ 7: 1099-1108.

KO K, KOPROWSKI H. (2005). Plant biopharming of monoclonal antibodies. Virus Res 111: 93-100.

KÖHLER G, MILSTEIN C. (1975). Continuous cultures of fused cells secreting antibody of predefined specificity. Nature 256: 495-497.

KOSTEN T, OWENS SM. (2005). Immunotherapy for the treatment of drug abuse. Pharmacol Ther 108: 76-85.

LOOS A, VAN DROOGENBROECK B, HILLMER S, GRASS J, KUNERT R, CAO J, ROBINSON DG, DEPICKER A, STEINKELLNER H. (2011a). Production of monoclonal antibodies with a controlled $\mathrm{N}$-glycosylation pattern in seeds of Arabidopsis Thaliana. Plant Biotechnol J 9: 179-192.

LOOS A, VAN DROOGENBROECK B, HILLMER S, GRASS J, PABST M, CASTILHO A, KUNERT R, LIANG M, ARCALIS E, ROBINSON DG, DEPICKER A STEINKELLNER H. (2011b). Expression of antibody fragments with a controlled $\mathrm{N}$-glycosylation pattern and induction of endoplasmic reticulum-derived vesicles in seeds of Arabidopsis. Plant Physiol 155: 2036-2048.

MA JK-C, HIATT A, HEIN M, VINE ND, WANG F, STABILA P, VAN DOLLEWEERD C MOSTOV K, LEHNER T. (1995). Generation and assembly of secretory antibodies in plants. Science 268: 716-719.

MAYFIELD SP, FRANKLIN SE. (2005). Expression of human antibodies in eukaryotic micro-algae. Vaccine 23: 1828-1832.

MORTS, MOONY-S, PALMER KE, MASON HS. (2003). Geminivirus vectors for highlevel expression of foreign proteins in plant cells. Biotechnol Bioeng 81: 430-437.

NAZRK, RAJESHC. (2004). Passive immunization for immunocontraception: lessons learned from infectious diseases. Front Biosci 9: 2457-2465.

OBEMBE OO, POPOOLAJO, LEELAVATHI S, REDDY SV. (2011). Advances in plant molecular farming. Biotechnol Adv 29: 210-222.

OLEKSIEWICZMB, NAGY G, NAGYE. (2012). Anti-bacterial monoclonal antibodies:
Back to the future? Arch Biochem Biophys 526: 124-131

OLINGER GG, JR., PETTITT J, KIM D, WORKING C, BOHOROV O, BRATCHER B, HIATT E, HUME SD, JOHNSON AK, MORTON J, PAULY M, WHALEY KJ, LEAR CM, BIGGINS JE, SCULLY C, HENSLEY L, ZEITLIN L. (2012). Delayed treatment of Ebola virus infection with plant-derived monoclonal antibodies provides protection in rhesus macaques. Proc NatlAcad Sci USA 109: 18030-18035.

PAUL M, MA JK-C. (2011). Plant-made pharmaceuticals: Leading products and production platforms. Biotechnol Appl Biochem 58: 58-67.

PAUL M, VAN DOLLEWEERD C, DRAKE PMW, RELJIC R, THANGARAJ H, BARBI T, STYLIANOU E, PEPPONI I, BOTH L, HEHLE V, MADEIRA L, INCHAKALODY V, HO S, GUERRA T, MA JK-C. (2011). Molecular pharming: future targets and aspirations. Hum Vaccin 7: 375-382.

PERRIN Y, VAQUERO C, GERRARD I, SACK M, DROSSARD J, STÖGER E, CHRISTOU P, FISCHER R. (2000). Transgenic pea seeds as bioreactors for the production of a single-chain Fv fragment (scFV) antibody used in cancer diagnosis and therapy. Mol Breeding 6: 345-352.

PETERS J, STOGER E. (2011). Transgenic crops for the production of recombinant vaccines and anti-microbial antibodies. Hum Vaccin 7: 367-374.

PETRUCCELLI S, OTEGUI MS, LAREU F, DINH OT, FITCHETTE A-C, CIRCOSTA A, RUMBO M, BARDOR M, CARCAMO R, GOMORD V, BEACHY RN. (2006). A KDEL-tagged monoclonal antibody is efficiently retained in the endoplasmic reticulum in leaves, but is both partially secreted and sorted to protein storage vacuoles in seeds. Plant Biotechnol J 4: 511-527.

POGUE GP, VOJDANI F, PALMER KE, HIATT E, HUME S, PHELPS J, LONG L, BOHOROVA N, KIM D, PAULY M, VELASCO J, WHALEY K, ZEITLIN L, GARGER SJ, WHITE E, BAI Y, HAYDON H, BRATCHER B. (2010). Production of pharmaceutical-grade recombinant aprotinin and a monoclonal antibody product using plant-based transient expression systems. Plant Biotechnol J 8: 638-654.

RAAB CP. (2011). Passive immunization. Prim Care: Clinics in Office Practice 38: 681-691.

RADEMACHER T, SACK M, ARCALIS E, STADLMANN J, BALZER S, ALTMANN F, QUENDLER H, STIEGLER G, KUNERT R, FISCHER R, STOGER E. (2008). Recombinant antibody 2 G12 produced in maize endosperm efficiently neutralizes HIV-1 and contains predominantly single-GlcNAc N-glycans. Plant Biotechnol J 6: 189-201.

RAMESSAR K, RADEMACHER T, SACK M, STADLMANN J, PLATIS D, STIEGLER G, LABROU N, ALTMANN F, MAJ, STÖGER E, CAPELL T, CHRISTOU P. (2008). Cost-effective production of a vaginal protein microbicide to prevent HIV transmission. Proc Natl Acad Sci USA 105: 3727-3732.

RYBICKI EP. (2010). Plant-made vaccines for humans and animals. Plant Biotechnol J 8: $620-637$

SAINSBURY F, SACK M, STADLMANN J, QUENDLER H, FISCHER R, LOMONOSSOFF GP. (2010). Rapid transient production in plants by replicating and non-replicating vectors yields high quality functional anti-HIV antibody. PLoS ONE 5: e13976

SAINSBURY F, THUENEMANN EC, LOMONOSSOFF GP. (2009). pEAQ: versatile expression vectors for easy and quick transient expression of heterologous proteins in plants. Plant Biotechnol J 7: 682-693.

SCHIRRMANN T, AL-HALABI L, DÜBEL S, HUST M. (2008). Production systems for recombinant antibodies. Front Biosci 13: 4576-4594.

SHARP JM, DORAN PM. (2001). Strategies for enhancing monoclonal antibody accumulation in plant cell and organ cultures. Biotechnol Prog 17: 979-992.

SMITH GP. (1985). Filamentous fusion phage: novel expression vectors that display cloned antigens on the virion surface. Science 228: 1315-1317.

STÖGER E, VAQUERO C, TORRES E, SACK M, NICHOLSON L, DROSSARD J, WILLIAMS S, KEEN D, PERRIN Y, CHRISTOU P, FISCHER R. (2000). Cereal crops as viable production and storage systems for pharmaceutical scFv antibodies. Plant Mol Biol 42: 583-590.

STREATFIELD SJ. (2007). Approaches to achieve high-level heterologous protein production in plants. Plant Biotechnol J 5: 2-15

TILLERT, MEFFRE E, YURASOV S, TSUIJI M, NUSSENZWEIG MC, WARDEMANN $H$. (2008). Efficient generation of monoclonal antibodies from single human $B$ cells by single cell RT-PCR and expression vector cloning. $J$ Immunol Methods 329: 112-124.

TRKOLAA, PURTSCHER M, MUSTER T, BALLAUN C, BUCHACHERA, SULLIVAN N, SRINIVASAN K, SODROSKI J, MOORE JP, KATINGER H. (1996). Human 
monoclonal antibody $2 \mathrm{G} 12$ defines a distinctive neutralization epitope on the gp120 glycoprotein of human immunodeficiency virus type 1. J Virol70: 1100-1108.

VAN DROOGENBROECK B, CAO J, STADLMANN J, ALTMANN F, COLANESI S, HILLMER S, ROBINSON DG, VAN LERBERGE E, TERRYN N, VAN MONTAGU M, LIANG M, DEPICKER A, DE JAEGER G. (2007). Aberrant localization and underglycosylation of highly accumulating single-chain Fv-Fc antibodies in transgenic Arabidopsis seeds. Proc Natl Acad Sci USA 104: 1430-1435.

VAN DROOGENBROECK B, DE WILDE K, DEPICKER A. (2009). Production of antibody fragments in Arabidopsis seeds. In Recombinant Proteins From Plants (Methods in Molecular Biology, Vol 483) Eds. FAYE L and GOMORD V). Humana Press, New York, pp.89-101.

VIRDI V, CODDENS A, DE BUCK S, MILLET S, GODDEERIS BM, COX E, DE GREVE H, DEPICKER A. (2013). Orally fed seeds producing designer IgAs protect weaned piglets against enterotoxigenic Escherichia coli infection. Proc Natl Acad Sci USA 110: 11809-11814.

VOINNET O, RIVAS S, MESTRE P, BAULCOMBE D. (2003). An enhanced transient expression system in plants based on suppression of gene silencing by the p19 protein of tomato bushy stunt virus. Plant J 33: 949-956.

WEBSTER DE, THOMAS MC. (2012). Post-translational modification of plant-made foreign proteins; glycosylation and beyond. Biotechnol Adv 30: 410-418.

WERNER S, MARILLONNET S, HAUSE G, KLIMYUK V, GLEBA Y. (2006). Immunoabsorbent nanoparticles based on a tobamovirus displaying protein A. Proc Natl Acad Sci USA 103: 17678-17683.
WHALEY KJ, HIATT A, ZEITLIN L. (2011). Emerging antibody products and Nicotiana manufacturing. Hum Vaccin 7: 349-356.

WURM FM. (2004). Production of recombinant protein therapeutics in cultivated mammalian cells. Nat Biotechnol 22: 1393-1398.

WYCOFF KL. (2005). Secretory IgA antibodies from plants. Curr Pharm Design 11: 2429-2437.

XU J, DOLAN MC, MEDRANO G, CRAMER CL, WEATHERS PJ. (2012). Green factory: Plants as bioproduction platforms for recombinant proteins. Biotechnol Adv 30: 1171-1184.

XU J, GE X, DOLAN MC. (2011). Towards high-yield production of pharmaceutical proteins with plant cell suspension cultures. Biotechnol Adv 29: 278-299.

ZEITLIN L, CONE RA, MOENCH TR, WHALEY KJ. (2000). Preventing infectious disease with passive immunization. Microbes Infect 2: 701-708.

ZEITLIN L, CONE RA, WHALEY KJ. (1999). Using monoclonal antibodies to prevent mucosal transmission of epidemic infectious diseases. Emerging Infect Dis 5: 54-64.

ZEITLIN L, PETTITT J, SCULLY C, BOHOROVAN, KIM D, PAULY M, HIATT A, NGO L, STEINKELLNER H, WHALEY KJ, OLINGER GG. (2011). Enhanced potency of a fucose-free monoclonal antibody being developed as an Ebola virus immunoprotectant. Proc Natl Acad Sci USA 108: 20690-20694.

ZIMMERMANN J, SAALBACH I, JAHN D, GIERSBERG M, HAEHNEL S, WEDEL J, MACEK J, ZOUFAL K, GLÜNDER G, FALKENBURG D, KIPRIYANOV SM. (2009). Antibody expressing pea seeds as fodder for prevention of gastrointestinal parasitic infections in chickens. BMC Biotechnol 9: 79 


\section{Further Related Reading, published previously in the Int. J. Dev. Biol.}

Reproductive Meristem22 is a unique marker for the early stages of stamen development Elisson Romanel, Pradeep Das, Richard M. Amasino, Jan Traas, Elliot Meyerowitz and Marcio Alves-Ferreira Int. J. Dev. Biol. (2011) 55: 657-664

Multi-probe in situ hybridization to whole mount Arabidopsis seedlings

Leonardo Bruno, Antonella Muto, Natasha D. Spadafora, Domenico laria, Adriana Chiappetta, Mieke Van Lijsebettens and Maria B. Bitonti Int. J. Dev. Biol. (2011) 55: 197-203

Common themes in siRNA-mediated epigenetic silencing pathways André Verdel, Aurélia Vavasseur, Madalen Le Gorrec and Leila Touat-Todeschini Int. J. Dev. Biol. (2009) 53: 245-257

Arabidopsis monomeric G-proteins, markers of early and late events in cell differentiation Mariette Bedhomme, Chantal Mathieu, Amada Pulido, Yves Henry and Catherine Bergounioux Int. J. Dev. Biol. (2009) 53: 177-185

Plant microRNAs and development

Sara Jover-Gil, Héctor Candela and María-Rosa Ponce

Int. J. Dev. Biol. (2005) 49: 733-744

Historical perspectives on plant developmental biology

Mieke Van Lijsebettens and Marc Van Montagu

Int. J. Dev. Biol. (2005) 49: 453-465

Molecular-genetic approach to study plant growth and development M Van Montagu, M Van Lijsebettens and D Inzé

Int. J. Dev. Biol. (1996) 40: S49-S50

Mechanisms of the proliferation and differentiation of plant cells in cell culture systems H Fukuda, M Ito, M Sugiyama and A Komamine

Int. J. Dev. Biol. (1994) 38: 287-299

5 yr ISI Impact Factor $(2011)=2.959$
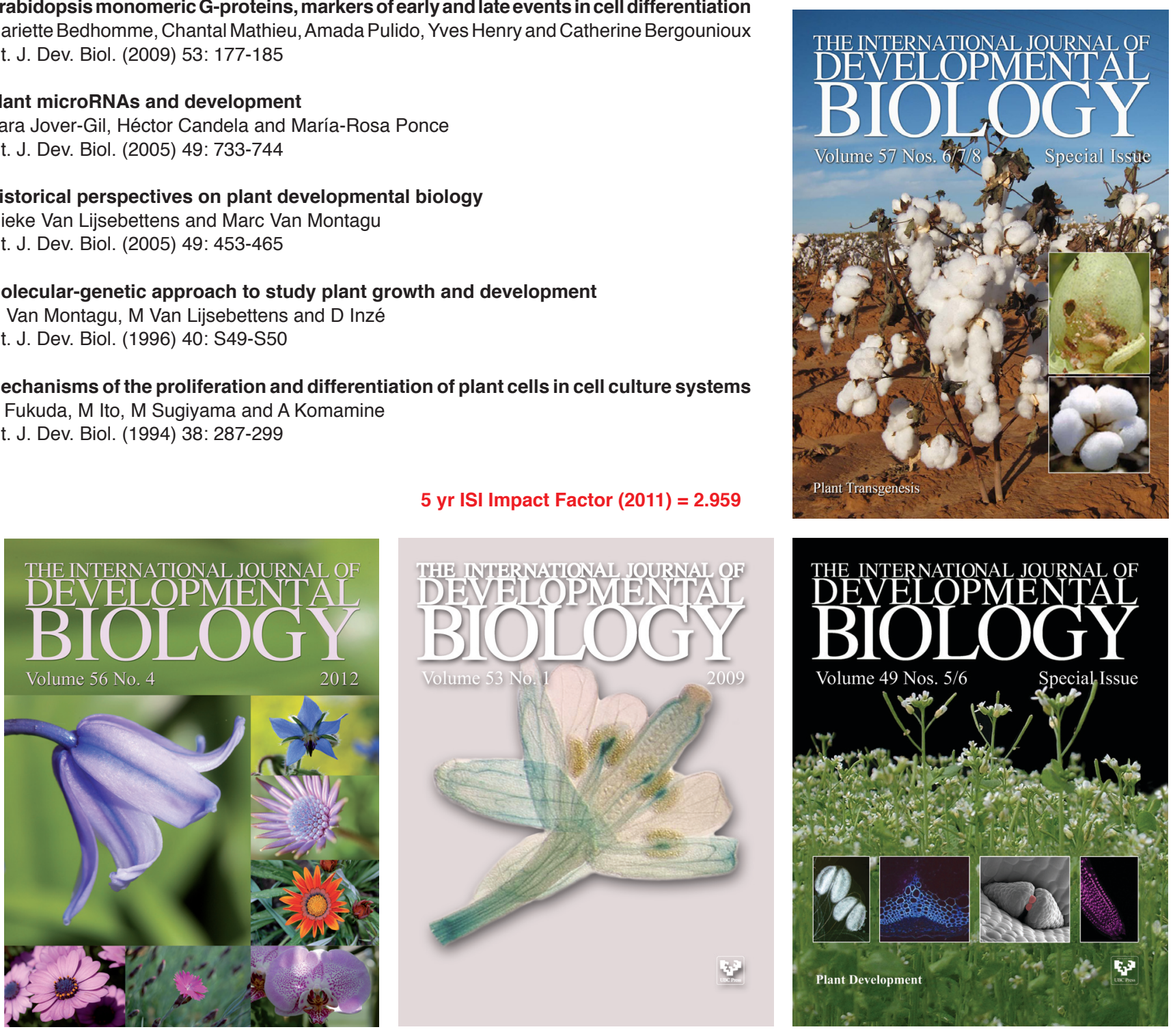